\title{
Financial Support System and Strategy of SMEs in the Incubation Based on Business Life Cycle
}

\author{
Yanjuan Cui \\ School of Finance, Dongbei University of Finance and Economics \\ School of Management, Dalian Polytechnic University \\ 1 Qing Gong Yuan, Gan Jing Zi, Dalian 116034, China \\ Tel: 86-411-8632-3622Ｅ-mail: tsuiyanjuan@163.com
}

Ling Zha

City College, Southwest University of Science and Technology

11 San Xing Road, You Xian, Mianyang 621000, China

Tel: 86-816-628-5106

Fenghai Zhang

School of Management, Dalian Polytechnic University

1 Qing Gong Yuan, Gan Jing Zi, Dalian 116034, China

Tel: 86-411-8632-3325

The research is financed by project for colleges and universities research 2009 of the Education Department of Liaoning Province. No. 2009 B029

\begin{abstract}
SMEs in the incubation are the main innovation of a nation, and the new product is not without SMEs technology innovation. It is not only the theoretical but also practical significance that SMEs in the Incubation develop strongly for economic growth and technology innovation, but as the normal SMEs, they also face the financial support difficulty or more others. This paper analyses the financial demand characters of SMEs in the incubation based on the theory of business life cycle. The conclusion is that different development phases need different financial support because SMEs in the incubation face different financial cycles. The financial support system is set up to fit the cycle needs of SMEs in the incubation, and then the suggestions are illustrated. The results can be the reference for the problems of financial support for SMEs in the incubation.
\end{abstract}

Keywords: SMEs in the incubation, Financial support system, Strategy, Business life cycle

\section{Introduction}

Business incubator is the important platform for SMEs developments and technology innovation. It is physical space for the business enterprise, sharing platform for business support services and vector for supporting enterprises starting and developing, so it is of great significance for employment, local economic growth and foreign investment (Deborah M. Markley \& Kevin T. McNamara, 1995). Business incubator is the service centers providing with physical space and infrastructure and a series of service support to reduce start-up costs and risk, improve the success rate of entrepreneurship and promote scientific and technological achievements, so the SMEs can develop and growth fast. Business incubator services as intermediary agent to strive for government finance besides supporting business itself. And they also strive for low interest loan, stock and project investment from bank, venture capital institution guaranteeing by incubators' credit and capital. SMEs in the incubation are the relative term to incubator. So-called SMEs in the incubation are those in the start-up stage and developed relying on certain environment. Those enterprises have so great financial gap that their development are restrained because of their high technology, less capital and greater risk. So the incubators are the important platform for SMEs in the incubation development.

The incubator for SMEs developed is one of venture capital, whose development makes up for the shortage of financial support. Some surveys showed that in North America about seventy five percent of tech business incubator had helped the clients obtain commercial bank loans or professional non-commercial bank loans and loan guarantees, and about sixty six percent incubator plan could help clients connecting with angel funds or 
venture capital investors, and thirty three percent could provide inner investment funds. And now in China, according to statistics of the Ministry of Science and Technology, there are more than ninety percent of small business entrepreneurs in the over 670 incubators and 60-university science park, and there are more than more than 54000 businesses in the incubation. As one of venture capital incubator can ease the financial shortage of SMEs in incubators, but financial difficulty is still the great problem for them. SMEs in the incubation are lack of endogenous financing, and the financial support of commercial bank, investment and credit guarantee services are limited, so the main disturbing factor of SMEs incubation is the imperfect financial support system, especially during the global finance crisis. While at the mean time, SMEs are indispensable force of technological innovation and economy development. Therefore, it is very significant to discuss financial support for SMEs in the incubation for China.

This paper overviews the related researches and literatures for studying the SMEs in the incubation, then analyzes the different finance demand based on the SMEs lifecycle, at last proposed financial support measures for SMEs are proposed. It hopes that this study can be helped for SMEs finance difficulties.

\section{Literature overview}

The theory basis for SMEs financial support is the capital structure theory and SMEs financial theory. The earlier study was MM theory, which suggested that corporate investment is irrelevant with financing policy and corporate financing structure does not affect the market value (Franco Modigliani \& Merton Miller, 1958). MM theory was revised that tax shield benefits and personal income tax could be offset so capital structure does not affect the value of the company under equilibrium condition (Miller, 1977). Later the trade-off theory relaxed some assumption that a company chooses how much debt finance and how much equity finance to use by balancing the costs and benefits (Robichek \& Mayer, 1966). Agency cost was given that the agency costs should be borne by the shareholders with the existence of external equity, and because of different effects of operators, shareholders and creditors, only the modest debt increasing in capital structure would increase the shareholder value (Jensen \& Meckling, 1976). The pecking order theory states that with asymmetric information, companies will use internal funds first, and when that is depleted, debt is issued, and when it is not sensible to issue any more debt, equity is issued (Myers \& Majluf, 1984). Corporate finance cycle hypothesis that enterprises can be divided into creation, growth and recession stages, which have the different financing sources such as own fund in creation stage, and credit, loans, leases, bonds in growth stage and so on (Weston \& Brigham, 1978).

SMEs financial theory is mainly based on the theory of credit ration and relationship banking. Credit rations theory refers that with asymmetric information the bank will imply the rate rationing system for lenders to avoid moral hazard and adverse selection when facing exceed demands for loans, so that SMEs will be difficult to access the appropriate finance (Stiglitz \& Weiss, 1981). Theory of relationship banking states that the large financial institutions typically provides services for large enterprises, while Medium and small financial institutions always establish cooperation relationship with SMEs easily for their advantages in information, therefore it will help solving the problems of finance difficulty resulted from asymmetric information of financial institution and SMEs (Berger, 1998). In China, the main research of SMEs finance started slower. Some research suggests that the fundamental way for removing the private economic and financial difficulties of SMEs is to create the external environment of endogenous growth financial system (ZHANG Jie, 2000). Some states that development and improvement of small and medium financial institutions is the important thing for China SMEs (LIN Yifu, 2001). While ZHONG Pengrong (2002), PENG Lei (2003) and BA Shusong (2006) all developed the arguments of different ways for SMEs finance.

All those researches have provided the theory and practice base for SMEs in incubators finance, and given the reference for improve the development of SMEs.

\section{Financial demand for SMEs in the incubation on the life cycle}

SMEs in the incubation are different with those out the incubation in less registered capital, larger ratio of technology staffs and own capital. So that it is very easy for SMEs in the incubation to take out asymmetric information, difficulty to manage and finance. Based on finance life cycle, the lifecycle of SMEs in the incubation can be classified as seed period, infant period, growth period, and maturity period and after the incubation period, such as the top of Figure 1 shown. Demands for finance support system are differed for the differences on the scale, capital demand and operation of each lifecycle period.

Seed period refers to that early into the incubation. SMEs in the incubation hold the project developed. Their invisible capital and risk are larger, and even the yield is negative, so that the bank credit and capital market funding are almost not be accessed. The main resources are from own capital, loans and deposits of family and friends. While if the project has great prospects, entrepreneurs can get government seeds fund, incubating fund 
and innovation fund etc on patents. Generally, SMEs during this period mainly get finance support from own capital and venture capital than others.

Infant period is that after seed. At this period, the own capital can't meet the enterprise development, so SMEs in the incubation during this period have to seek for the external financing. However, there is still higher risk and lower yield, so that business angels but bank load is employed. Business angels are very important here,that business angels provide not only the fund but also the service of management consulting, technical supporting and information network.

During the growth period SMEs in the incubations have developed stably. They need a great of capital to enlarge the production, improve the quality and brand, so that they must to seek for the external finance such as venture capital, as limited partnership limiting the investors' liability to decrease the risk of asymmetric information.

SMEs in the incubations during the maturity period have increasing yield and risk reduction. And with much more mortgage assets, SMEs can get finance of initial public offering (IPO) including debt and bank finance. IPO can reduce the finance cost greater than others. Another method is to get the bank loan because at this period SMEs have has the higher yields.

After the incubating period, there are little protections for SMEs have graduated from the incubations. So that the institutional investors and banks have been the main capital sources. And SMEs will incubate successfully only if the endogenous and external financing are combined effectively.

\section{Strategies and support system for SMEs in the incubation}

Based on the different financial demand on the life cycle, the financial support system for SMEs in the incubation can be established. As the bottom of Figure.1 shown, it is make the government polices as guidance, incubation as the platform, capital market and banks loan etc. as multi-channel capital supply and develop the institution's functions to improve the finance support system for SMEs in the incubation.

\subsection{Increase the government policy support range}

The government policy and service is the favor back force and make good developed environment for SMEs in the incubation, such as the preferential tax, interest loans and discount etc. An effective way is to set up special funds for those fitting national industry policy and innovation to provide loan assistance and security, e.g. Science and Technology (Development) Fund, Guarantee Fund, Mutual funds and special sector fund and so on.

In addition, the government, joint with local research institutions such as universities, commerce chamber etc., can provide the service in legal advice, policy recommendations, marketing management, finance and training etc in order to improve the developments of SMEs in the incubation.

\subsection{Develop the incubation for SMEs}

Incubation is the incubation platform for SMEs. However, they differ form each other for the difference of SMEs and actual developments in various regions. Therefore, the development of incubations is based on the local circumstances, e.g. University Park Incubation can be established around the university and so on. It is one of best ways for solving the financial problems of SMEs in the incubation to plan and guide the incubator playing the role of intermediary and platform to strive for low interest loan, stock investment and project investment from bank and venture capital institutions.

\subsection{Play the role of capital market effectively}

Capital market has been the direct financing channel. Multiple capital markets, especially the growth enterprise market (GEM) and SME board market, can satisfy the financial demand of SMEs in the incubation. At the meanwhile, the bond market can be used for the SMEs in the incubation with sound capital structure, adequate financial information disclosure and good reputation. Then the financial gaps can be covered by the capital effectively.

\subsection{Develop financial institution function}

Financing channel mainly with commercial bank, medium and small banks and other can satisfy the different demand of SMEs in the incubation. The following can be suggested.

Firstly, State-owned commercial banks are very important. They have the advantages of wider network, more capital and talent etc so they can innovate multiple finance products, strengthen the service consciousness and try establishing special service window for SMEs to provide special service for SMEs in the incubation. If possible, the state-owned commercial banks can cooperate with enterprise to set up venture capital and professional property exchange center to service as the bridge of the SMEs in the incubation with the large enterprises. 
Secondly, local small and medium financial institutions are important too. For instance, free interest, low-interest or even discount loans can be offered to those needs supporting in deed. And the information can be grasped to solve the financial gap of SMEs in the incubation during the different lifecycle period,.

Thirdly, Private capital could be encouraged into the financial support system. Private capital plays an important role in the different lifecycle period, especially during the seed period and infant period. Compared with bank finance, private capital can reduce the risk from asymmetric information. So the government can guide the private capital connecting with the SMEs in the incubation and make it become the important capital source for SMEs incubating.

Fourthly, professional financial leasing sector can be constructed, and then SMEs in the incubation can obtain the necessary equipment with rental. Financial leasing is the practice method for solving the financial gap of SMEs in the incubation.

Lastly, new financial service such as trade credit, logistics finance and insurance finance etc, can be used to meet the needs of SMEs in the incubation during the different stages. Trade credit is the cash or commodity credit provided between importers and exporters, or provided by bank, government or international finance institution to traders. This financial support in international trade not only solves the financial difficulty but also provides related services of notes or credit guarantee through by bank or other finance institution. Logistics finance, which organizes the money flow in logistic area through all kinds of financial products, can be used as an effective complement during different stages, and avoid the risk of asymmetric information with the characteristics of logistics companies charging the businesses goods. Furthermore, insurance finance can be tried to resolve financing techniques risk, which can provide insurance with services mortgage and guarantee.

\subsection{Perfect legal and credit Guarantee}

SMEs in the incubation are different from common ones in absence of effective competition. So the related laws, regulations and business environment should be improved to safeguard the legitimate rights and interests of SMEs in the incubation. Local government should draft policy documents to encourage and protect their developments.

With the development and graduation after incubating maturity, the bank loans become the main finance method. However, there is absent of appropriate security and collateral. The incubation can give only a little help. So SMEs information website, credit database and credit guarantee institutions can be used to make that cooperate coordinately with financial institutions.

\subsection{Enlarge the service range by industry association}

Industry association can help to establish enterprise information database, so the enterprises can know about information of market and policy in time, grasp the common problems of industry development, and promote to study with each other. Then the SMEs in the incubation can develop quickly and strengthen their own construction to obtain all channels of finance.

\section{Conclusion}

The incubator for SMEs, as one of venture capital in fact, has make up the finance shortage. Incubation together with bank, capital market, institution security and government has established the integrated finance support system for SMEs in the incubation.

\section{References}

Alexander A. Robichek, \& Stewart C. Myers. (1966). Problems in the theory of optimal capital structure. Journal of Financial and Quantitative Analysis, 1, 1-35.

Berger, A. N., A. Saunders, J.M. Scalise, \& G. F. Udell. (1998), The effects of bank mergers and acquisitions on small business lending. Journal of Financial Economics, 50, 187-229.

Cardullo, Mario W. (1999). Technological entrepreneurism: enterprise formation, financing and growth, England: Research Studies Press Ltd, pp56.

Deborah M. Markley, \& Kevin T. McNamara. (1995). Economic and fiscal impacts of a business incubator. Economic Development Quarterly, 9, 273-278.

Jensen, M. \& W. R. Meckling. (1976). Theory of the firm, managerial behavior, agency costs and ownership structure. Journal of Financial Economics, 6, 305-360.

J. F. Weston \& E F. Brigham (1978). Managerial finance. (6th ed). The Dryden Press, pp 45-60-708. 
LIN, Yifu \& LI, Yongjun. (2001). Finance of Medium and Small-sized Enterprises and the Development of Medium and Small-sized Financial Institutions. Economic Research Journal, 1, 10-18,53

Merton H. Miller. (1977). Debt and taxes. Journal of Finance, 32, 261-275

Modigliani, F., \& M. Miller (1958). The cost of capital, corporate finance, and the theory of investment. The American Economic Review, 48, 261-297

Myers, S., \& N. Majluf. (1984). corporate financing and investment decisions when firms have information that investors do not have. Journal of Financial Economics, 13, 187-221

Stiglitz, J. \& A. Weiss (1981). Credit rationing in markets with incomplete information. American Economic Review, 71, 393-410

ZHANG, Jie. (2000). The financing dilemma and pecking order of the people-run economy. Economic Research Journal, 4, 3-10

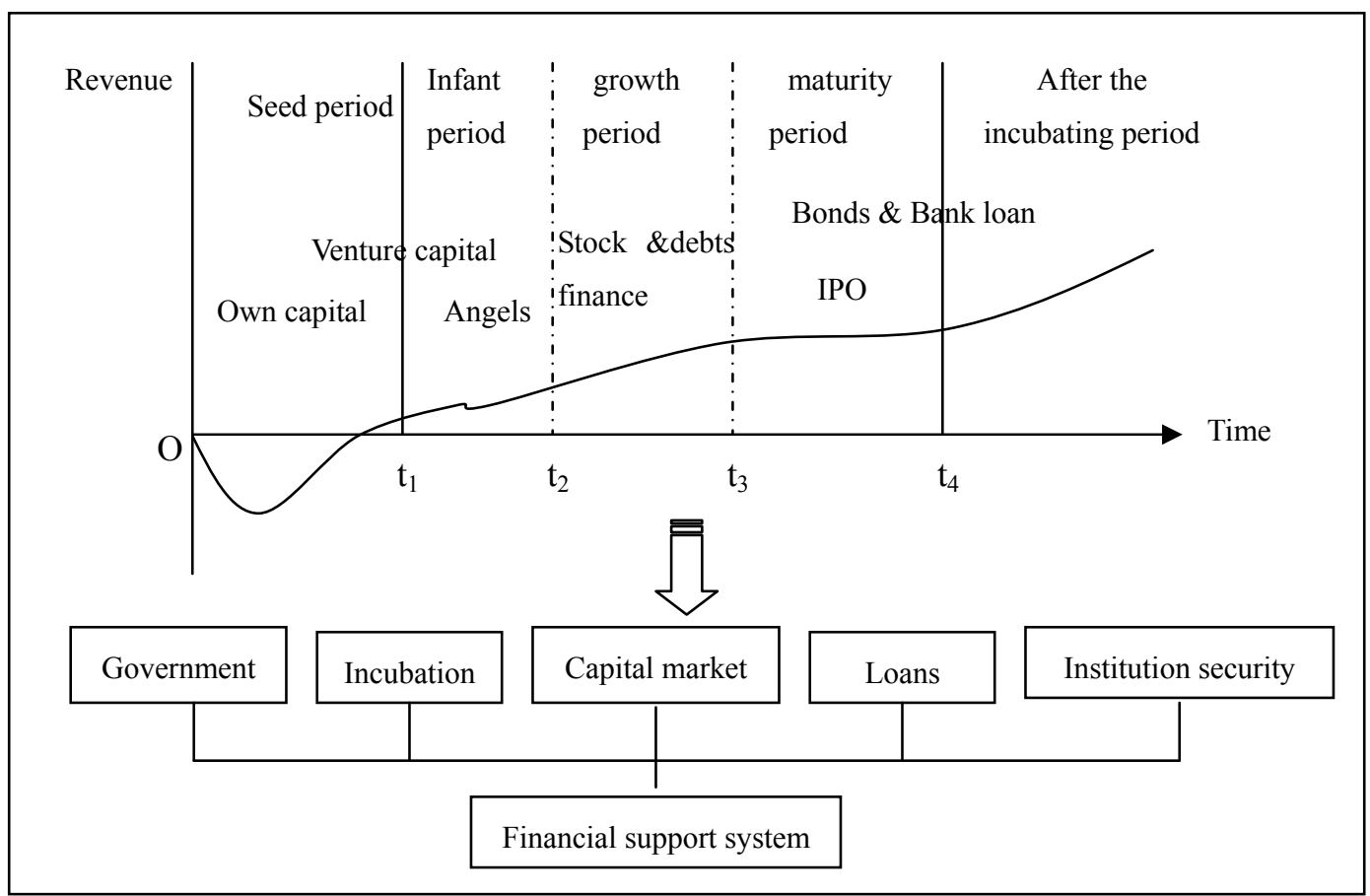

Figure 1. Financial Demand Characteristics on the Life Cycle and Support System for SMEs in the Incubation 